\title{
Effect of drying methods and packaging on retention of carotenoid pigment in dried petals of marigold $\mathrm{cv}$. seracole
}

\author{
Sangita Mahanta*, Madhumita Choudhury Talukdar and Priyanka Das ${ }^{1}$ \\ Department of Horticulture, Assam Agricultural University, Jorhat (Assam) India
}

(Email: sangitamahanta2@gmail.com)

\begin{abstract}
An experiment was conducted in Department of Horticulture, Assam Agricultural University, Jorhat, to study the effect of drying methods and packaging on retention of carotenoid content in dried petals of marigold cv. Seracole during 2016-2017. Petals were subjected to drying employing three different methods viz., sun drying, shade drying and cabinet drying. Among the various drying methods tested, cabinet drying gave the highest carotenoid content $(337.64 \mu \mathrm{g} / \mathrm{g})$ compared to the other methods. Three different packaging materials viz., LDPE 200 gauge, LDPE 300 gauge and LDPE 400 gauge were utilized for the experiment. The carotenoid content was highest in the first month with LDPE packaging materials of 400 gauge $(270.47 \mu \mathrm{g} / \mathrm{g}), 300$ gauge $(269.64 \mu \mathrm{g} / \mathrm{g})$ and 200 gauge $(266.94 \mu \mathrm{g} / \mathrm{g})$ which decreased with advancement of storage period.
\end{abstract}

Key Words : Marigold, Carotenoid, Drying methods, Packaging, LDPE

View Point Article : Mahanta, Sangita, Talukdar, Madhumita Choudhury and Das, Priyanka (2021). Effect of drying methods and packaging on retention of carotenoid pigment in dried petals of marigold cv. seracole. Internat. J. agric. Sci., 17 (2) : 582-585, DOI:10.15740/ HAS/IJAS/17.2/582-585. Copyright@ 2021: Hind Agri-Horticultural Society.

Article History : Received : 22.03.2021; Revised : 25.03.2021; Accepted : 03.04.2021

\footnotetext{
* Author for correspondence :

${ }^{1}$ Department of Biochemistry and Agricultural Chemistry, Assam Agricultural University, Jorhat (Assam) India
} 